\title{
DIAGNOSIS OF FUNGAL AND PARASITIC DERMATOPATHIES IN DOGS AND CATS OF PARAÍBA STATE, BRAZIL
}

\author{
DIAGNÓSTICO DE DERMATOPATIAS FÚNGICAS E PARASITÁRIAS EM CÃES E GATOS NA \\ PARAÍBA, BRASIL
}

\author{
B. A. VALENCIO ${ }^{1}$, V. L. R. VILELA ${ }^{2 *}$, T. F. FEITOSA ${ }^{3}$, I. C. SALES ${ }^{4}$, S. S. SILVA ${ }^{5}$, \\ A. L. ARAÚJO6
}

\section{SUMMARY}

This study aimed to diagnose fungal and parasitic dermatopathies, describing its casuistry in dogs and cats at the Veterinary Hospital (VH) of the Instituto Federal da Paraíba (IFPB), Sousa, Paraíba. The study was carried out at the Laboratory of Immunology and Infectious Diseases (LIID) and at the Small Animal Medical Clinic (SAMC), VH/IFPB, Sousa, Paraíba, Brazil. Fifty-eight animals with skin lesions, including 41 dogs and 17 cats, were evaluated. Samples from the lesions were processed, resulting in $12.2 \%$ (5/41) of dogs testing positive for dermatophytes; $60 \%$ (3/5) of those cases were confirmed with Microsporum canis infections. For scabies, 24.4\% (10/ 41) of dogs tested positive; of these, $80 \%(8 / 10, \mathrm{p} \leq 0.05)$ had Demodex canis infections. In cats, $17.6 \%$ (3/17) were positive for dermatophytes; of these, $67 \%$ (2/3) were confirmed to have Microsporum gypseum infections. The positive testing rate for scabies in cats was $17.6 \%$ (3/17); of these, $67 \%(2 / 3)$ were Notoedres cati infections. In one cat, a concomitant infection was found witha dermatophyte (M. gypseum) and scabies $(N$. cati). It was concluded that the occurrence of dermatopathies is high at the SAMC/VH/IFPB. The main dermatophytes found were M. canis in dogs and M. gypseum in cats, and the most frequent scabies were $D$. canis in dogs and $N$. cati in cats.

KEY-WORDS: Demodex spp.; dermatomycoses; Microsporium spp; Notoedres sp., scabies.

\section{RESUMO}

O objetivo desse trabalho foi diagnosticar as dermatopatias fúngicas e parasitárias, descrevendo a casuística dessas enfermidades em cães e gatos no Hospital Veterinário do Instituto Federal da Paraíba - IFPB, campus Sousa, ParaíbaPB. O experimento foi realizado no Laboratório de Imunologia e Doenças Infectocontagiosas - LIDIC e na Clínica Médica de Pequenos Animais - CMPA, HV/IFPB. Foram avaliados 58 animais, sendo 41 cães e 17 gatos. As amostras coletadas para as análises laboratoriais foram pelos e crostas das lesões. Obtiveram-se 12,2\% (5/41) dos cães positivos para dermatófitos, destes, 60\% (3/5) para Microsporum canis. Para sarnas, 24,4\% (10/41) dos cães foram positivos, em $80 \%(8 / 10 ; p \leq 0,05)$ a infestação era por Demodex canis. Nos gatos, $17,6 \%$ (3/17) foram positivos para dermatófitos, destes, 67\% (2/3) Microsporum gypseum. A positividade para sarnas em gatos foi 17,6\% (3/17), destes, 67\% (2/3) para Notoedres cati. Em apenas um felino foi encontrada infecção concomitante entre dermatófito (M. gypseum) e sarna (N.cati). Concluiu-se que é alta a casuística de dermatopatias na CMPA/HV/IFPB. O principal dermatófito encontrado em cães foi M. canis e em gatos M. gypseum. Dentre as sarnas Demodex spp. foi a mais frequente para cães e Notoedres sp. para gatos.

PALAVRAS-CHAVE: Demodex spp.; Dermatomicose;, Microsporium spp.; Notoedressp.; sarnas.

\footnotetext{
${ }^{1}$ Mestranda do Departamento de Medicina Veterinária Preventiva, Universidade de São Paulo- São Paulo- SP - Email.:

biancavalencio03@gmail.com

${ }^{2}$ Docente do Departamento de Medicina Veterinária, Instituto Federal da Paraíba -IFPB, campus Sousa-PB. *Autor para correspondência. - Email.: vilelavlr@yahoo.com.br

${ }^{3}$ Docente do Departamento de Medicina Veterinária, Instituto Federal da Paraíba -IFPB, campus Sousa-PB. - Email.: feitosa_tf@ yahoo.com.br

${ }^{4}$ Médico Veterinário autônomo - Ipaumirim- CE - Email.: italloifpbvet@ gmail.com

${ }^{5}$ Discente em Medicina Veterinária, Instituto Federal da Paraíba -IFPB, campus Sousa-PB - Email.: samarasilva.cz@gmail.com

${ }^{6}$ Docente do Departamento de Medicina Veterinária, Instituto Federal da Paraíba -IFPB, campus Sousa-PB. - Email.: araujonascal@ gmail.com
} 


\section{INTRODUCTION}

Diseases of the integumentary system are the most frequent in small animal outpatient clinics, either as primary complaints or as secondary diseases (MEGID et al., 2016). The main dermatopathic diseases are scabies, dermatophytosis, and pyoderma (MORIELLO \& DEBOER, 2012).

Dermatophytosis presents signs similar to other dermatopathies, such as alopecia and desquamation especially on the face, ears, limbs, and tail (MEGID et al., 2016). The majority of the diagnoses are made only through the animal's history and epidemiological data, which increases the chances of erroneous results and does not identify the pathogen in order to direct treatment decisions (BOND, 2010). Considered zoonotic, dermatophytosis of pet animals deserves special attention, since these animals maintain contact with humans, particularly children. According to Moriello \& Deboer (2012), dermatophytosis is most frequently caused by pathogenic fungi of the genera Microsporum, Trichophyton and Epidermophyton. These dermatophytes infect dogs and cats of all ages; however, old and immunosuppressed animals are more susceptible.

Traditional fungal culture is the method used to confirm the diagnosis of dermatophytosis, and it can be performed in test tubes, microscopic slides, and Petri dishes containing culture media for dermatophytes (SIDRIM \& ROCHA, 2004). The fungal culture Dermatobac $\AA$ is a culture slide containing three culture media, D.T.M., Sabouraud Selective Glucose, and BIGGY, for isolating dermatophytosis-producing fungi. It is an easy test to perform, is selective for fungi, and promotes the multiplication of dermatophytes, while inhibiting the growth of saprophytic fungi. At 72 hours of incubation, it indicates that the animal has the disease through observed alteration in the coloration of the culture medium. After 21 days of incubation, observing the fungal structures can determine the pathogenic species of fungus causing dermatophytosis, making it a reliable method for diagnosis and directing the correct treatment.

Scabies cause inflammation with intense itching, which then causes the appearance of wounds through bites, hemorrhagic crusts, and loss of hair (PICCININ et al., 2008). The scabies mites that cause this disease are Sarcoptes scabiei, Notoedres cati, Otodectes cynotis, and Demodex canis, which occurs frequently in dogs and cats (NEUWALD et al., 2004).

The most commonly used diagnostic method for scabies is the Direct Microscope Exam (DME), since adult mites and their eggs can be observed through the optical microscope in samples from skin scraping of the lesions. Besides being easy to perform, this test has a low cost and high sensitivity (BENSIGNOR, 2003).

Therefore, the objective of this study was to evaluate the casuistry of scabies and dermatophytosis in dogs and cats at the Veterinary Hospital (VH) of Instituto Federal da Paraíba (IFPB), Sousa-PB campus, using as the diagnostic methods of DME for scabies and Dermatobac $®$ for Dermatophytosis.

\section{MATERIAL E MÉTHODS}

This study was approved by the Research Ethics Committee of Universidade Federal de Campina Grande under protocol number 118/2016 CEP.

The study was carried out at the Laboratory of Immunology and Infectious Diseases (LIID) and at the Small Animal Medical Clinic (SAMC), VH/IFPB, Sousa-PB.

For this study, 41 dogs and 17 cats that had consultations at the SAMC with signs suggestive of dermatophytosis between April and December 2016 were selected. Biopsy was performed at the lesion sites hair and crusts were collected for laboratory analysis by scraping the borders of the lesions with a sterile blade (SANTAREM, 2007).

After the collection, the samples were placed in threaded, sterilized collecting tubes, properly identified, and sent to LIID for processing. All samples were first submitted to DME, according to Silva et al. (2008), and then seeded in the Dermatobac ${ }^{\circledR}$ cultures. After $72 \mathrm{~h}$ of incubation in B.O.D. at $28^{\circ} \mathrm{C}$ in the dark, a color change in the D.T.M medium occurred in the positive samples. After 21 days of incubation, the fungal structures were identified in Sabouraud Selective Glucose medium for the diagnosis of the pathogenic species (MORIELLO, 2014).

Data were collected from the clinical files of the animals, which were comprised of the cases along with the results of the analyses from the SAMC/VH/IFPB. The data collected included the location of the lesions, any differences in susceptibility between species (dogs and cats), sexes, ages, breed, any concurrent diseases, and the main causative agents of the disease.

The analysis of occurrence distribution was performed using the chi-square test, with $\mathrm{p} \leq 0.05$ indicating statistical significance (STREINER \& NORMAN, 1994).

\section{RESULTS AND DISCUSSION}

Were examined 359 animals at the SAMC/VH, including $245 \mathrm{dogs}$ and 105 cats. Of these, 16\% $(41 / 254)$ of dogs and $16.2 \%(17 / 105)$ of cats presented clinical signs suggestive of dermatopathies. This percentage is in agreement with reports in the literature that animals with dermatological afflictions represent between $15-25 \%$ of the visits to veterinary clinics (HIIL et al., 2006). Among the animals with signs suggestive of dermatopathies, $53.7 \%$ (22/41) of the dogs were male and $46.3 \%$ female; and $53 \%(9 / 17)$ of cats were male and $47 \%(8 / 17)$ female.

Of the dogs with dermatopathies, only $12.2 \%$ $(5 / 41)$ were positive for dermatophytes. Of these, $60 \%$ (3/5) tested positive for Microsporum canis, 20\% (1/5) for Microsporum gypseum, and $20 \%$ (1/5) for Trichophyton mentagrophytes. A higher prevalence of M. canis was observed by (NEVES et al., 2011), who evaluated the pathogens related to dermatophytosis in dogs and cats treated at the $\mathrm{VH}$ at the Universidade 
Federal de Mato Grosso, where 96.78\% (270/279) of the dogs presented M. canis.

Among the cats with dermatopathies, $17.6 \%$ (3/17) were positive for dermatophytes. Of these, $67 \%$ (2/3) tested positive for M. gypseum, and 33\% (1/3) for Epidermophyton sp. These results do not agree with those presented by Nweze (2011), who evaluated 47 cats, and $53.2 \%$ were positive for $M$. canis. The data may be divergent due to the reduced number of animals evaluated in both studies.

On DME, $24.4 \%$ (10/41) of dogs were positive for scabies. Of these, $80 \%(8 / 10 ; \mathrm{p} \leq 0.05)$ were diagnosed with $D$. canis and $20 \%(2 / 10)$ with $S$. scabiei. Demodicosis was also more prevalent in a study conducted by Rocha et al. (2008), who evaluated $412 \operatorname{dogs}$ from the $\mathrm{VH}$ of the Universidade Federal Rural do Semiárido, Mossoró-RN. They observed an $18.6 \%$ (77/412) positivity for scabies, with $90.9 \%$ (70/77) of these positive for D. canis and 9\% (7/77) positive for S. scabiei.

The positivity for scabies in cats in this study was $17.6 \%(3 / 17)$. Of these, $67 \%(2 / 3)$ were positive for $N$. cati and $33 \%$ for D. cati (1/3). These values are in agreement with (ROCHA et al., 2008), who evaluated 26 cats positive at the VH/UFERSA, and $69.2 \%(18 / 26)$ were positive for $N$. cati.

Of the 58 dogs and cats whose samples were evaluated, only one 2-year-old female cat, domiciled, of an unspecified breed, with crusts in the head region, had a concomitant infection with both scabies ( $N$. cati) and a dermatophyte (M. gypseum). To our knowledge, this is the first report of such a co-infection, as we were unable to find other cases in the consulted literature. The scarce reports of associated infection between scabies and fungi describe co-infections with malasseziosis and demodicosis in dogs (NOBRE et al., 1998; MACHADO et al., 2004); sporotrichosis and demodicosis in dogs (MATOS et al., 2012); and sporotrichosis, demodicosis, and pediculosis in cats (PEREIRA et al., 2005).

Table 1 shows the relationship between the age groups and the frequencies of fungal and parasitic infections.

Table 1 - Relation between age groups and occurrence of fungal and parasitic dermatological infection in animals treated at SAMC/VH/IFPB, Sousa, State of Paraíba, Brazil

\begin{tabular}{|c|c|c|c|c|c|c|}
\hline & & $\begin{array}{c}\text { Dogs } \\
\text { Dermatophytes }\end{array}$ & Scabies & & $\begin{array}{c}\text { Cats } \\
\text { Dermatophytes }\end{array}$ & Scabies \\
\hline & Attended & $\begin{array}{c}\text { Positives } \\
(\%)\end{array}$ & $\begin{array}{c}\text { Positives } \\
(\%)\end{array}$ & Attended & $\begin{array}{c}\text { Positives } \\
(\%)\end{array}$ & $\begin{array}{c}\text { Positives } \\
(\%)\end{array}$ \\
\hline $0-6$ months & 4 & - & $1(25)$ & 4 & $1(25)$ & - \\
\hline 6 months -1 year & 7 & $1(14,3)$ & $2(28,6)$ & 2 & - & - \\
\hline $1-3$ years & 9 & - & $4(44,4)$ & 6 & $1(16,7)$ & $1(16,7)$ \\
\hline 3 - 5 years & 6 & $1(16,7)$ & $2(33,3)$ & 3 & $1(33,3)$ & $1(33,3)$ \\
\hline$>5$ years & 15 & $3(20)$ & $1(6,7)$ & 2 & - & $1(50)$ \\
\hline Total & 41 & $5(12,2)$ & $10(24,4)$ & 17 & $3(16,7)$ & $3(16,7)$ \\
\hline
\end{tabular}

Of the dogs that tested positive for dermatophytes, $20 \%(3 / 15)$ were $\geq 5$ years old. Among cats, $33.3 \%(1 / 3)$ were $3-5$ years old. These data do not agree with other studies showing that young dogs and cats, especially animals up to 12 months old, are more susceptible to developing dermatophytosis (CAFARCHIA et al., 2004). Among dogs that were positive for scabies, $44.4 \%$ (4/9) had an age range of 13 years. Among cats positive for scabies, $50 \%(1 / 2)$ were $\geq 5$ years old. In this study, the reduced number of animals positive for fungi and scabies may have influenced this information.

As stated above, $53.5 \%(22 / 41)$ of the dogs in the study were male and $46.3 \%$ (19/41) were female. Of the dogs positive for dermatophytosis, $80 \%$ (4/5; $\mathrm{p} \leq 0.05)$ were male and $20 \%(1 / 5)$ were female. These data do not corroborate with those of Neves et al. (2011), who did not find any sex-related predisposition in a study carried out in $\mathrm{VH}$ at the Universidade Federal de Mato Grosso. The possible predisposing factor for the higher percentage of males may be the free open access to the street, since it exists for $77.3 \%$ $(17 / 22)$ of males and only $31.6 \%(6 / 19)$ of females evaluated.

Among the cats evaluated, 53\% (9/17) were male and $43 \%(8 / 17)$ were female. Among those positive for dermatophytosis, $67 \%(2 / 3)$ were male and $33 \%(1 / 3)$ were female. No sexual predisposition was found, which supports a finding already described in the literature by Lima (2016).

Table 2 describes the relationship between breed pattern and occurrence of fungal and parasitic infections.

The most frequent agent causing dermatophytosis of dogs was $M$. canis, with $7.3 \%$ (3/41). This finding corroborates with Palumbo et al. (2010), who observed $79.7 \%(102 / 128)$ of M. canis positive cases among the animals treated at the Department of Dermatology of the Faculdade de Medicina Veterinária of UNESP, Botucatu-SP. 
Table 2 - Breed pattern of dogs evaluated at SAMC/VH/IFPB with positive diagnoses for fungal or parasitic dermatological infections, Sousa, State of Paraíba, Brazil.

\begin{tabular}{|c|c|c|c|c|c|c|}
\hline \multirow[b]{3}{*}{ Breed pattern } & \multirow[b]{3}{*}{ Attended } & \multicolumn{3}{|c|}{ Fungi Dermatophytes } & \multicolumn{2}{|c|}{ Scabies } \\
\hline & & M. canis & M. gypseum & T. mentagrophytes & S. scabiei & D. canis \\
\hline & & $\begin{array}{c}\text { Positives } \\
(\%)\end{array}$ & $\begin{array}{c}\text { Positives } \\
(\%)\end{array}$ & $\begin{array}{c}\text { Positives } \\
(\%)\end{array}$ & $\begin{array}{c}\text { Positives } \\
(\%)\end{array}$ & $\begin{array}{c}\text { Positives } \\
(\%)\end{array}$ \\
\hline Pit Bull & 5 & - & - & - & - & $2(40)$ \\
\hline Unspecified & 17 & - & - & - & $1(5,9)$ & $3(17,6)$ \\
\hline Pinscher & 4 & - & - & - & - & $2(50)$ \\
\hline Poodle & 5 & $1(20)$ & - & - & $1(20)$ & \\
\hline Labrador & 3 & - & - & $1(33,3)$ & - & - \\
\hline Yorkshire & 3 & $2(66,7)$ & - & - & - & - \\
\hline Bulldog & 4 & - & $1(25)$ & - & - & $1(25)$ \\
\hline Total & 41 & $3(7,3)$ & $1(2,4)$ & $1(2,4)$ & $2(4,8)^{\mathrm{a}}$ & $8(19,5)^{b}$ \\
\hline
\end{tabular}

Values followed by different letters differ statistically from each other $\left({ }^{*} \mathrm{p} \leq 0.05\right)$.

Concerning dog breed data in this study, $50 \%$ (2/4) were Pinschers and 40\% (2/5) were Pit Bulls, corroborating with Rocha et al. (2008), who observed prevalences of demodicosis in the Pinscher and Pit Bull breeds of $17.6 \%$ and $40.5 \%$, respectively. According to Scott et al. (2001), demodicosis presents a predisposition in brachycephalic animals, such as English Bulldog, Boxer and Pittbull Terriers, it is believed that these animals present a genetic defect in the specific immune response against $D$. canis. In addition, hyperadrenocorticism, hypothyroidism, diabetes mellitus, malignant neoplasms and leishmaniasis are other diseases that may be associated with demodicosis (MEDLEAU \& HILICICA, 2006). All of the felines used in the research were unspecified breeds, so there was no way to relate the incidence of fungal and parasitic infections to breed traits.

Table 3 shows the clinical signs presented by the animals in this study and their relation with the incidence of fungal and parasitic infections.

Table 3 - Clinical signs observed in animals evaluated at SAMC/ VH/IFPB with positive diagnoses of fungal and parasitic dermatological infections, Sousa, State of Paraíba, Brazil.

\begin{tabular}{|c|c|c|c|c|c|c|}
\hline Clinical signs & Attended & $\begin{array}{c}\text { Dogs } \\
\text { Dermatophytes } \\
\text { Positives } \\
(\%)\end{array}$ & $\begin{array}{l}\text { Scabies } \\
\text { Positives } \\
(\%)\end{array}$ & Attended & $\begin{array}{c}\text { Cats } \\
\text { Dermatophytes } \\
\text { Positives } \\
(\%)\end{array}$ & $\begin{array}{l}\text { Scabies } \\
\text { Positives } \\
(\%)\end{array}$ \\
\hline Alopecia/hypotrichosis & 3 & - & $2(66,7)$ & 3 & - & $1(33,3)$ \\
\hline $\begin{array}{l}\text { Alopecia }+ \\
\text { desquamation }\end{array}$ & 10 & $2(20)$ & $1(10)$ & 4 & $1(25)$ & - \\
\hline Alopecia + pruritus & 12 & $1(8,3)$ & $2(16,7)$ & 5 & $1(20)$ & $1(20)$ \\
\hline $\begin{array}{l}\text { Alopecia }+ \\
\text { desquamation }+ \text { itching }\end{array}$ & 8 & $2(25)$ & $3(37,5)$ & 2 & - & - \\
\hline $\begin{array}{l}\text { Alopecia + pruritus + } \\
\text { ectoparasites }\end{array}$ & 2 & - & $1(50)$ & - & - & - \\
\hline Hyperkeratosis & 6 & - & $1(16,7)$ & - & - & - \\
\hline Crusts & - & - & & 3 & $1(33,3)$ & $1(33,3)$ \\
\hline Total & 41 & $5(12,2)$ & $10(24,4)$ & 17 & $3(17,6)$ & $3(17,6)$ \\
\hline
\end{tabular}

Among the dogs that tested positive for dermatophytes, $20 \%(2 / 10)$ had alopecia and desquamation. Regarding the three felines positive for dermatophytosis, $20 \%(1 / 5)$ had alopecia and pruritus. Alopecia was the most common clinical sign in dermatophytosis, as was also described by Neves et al. (2011), who reported alopecia in all dermatophytepositive animals that were treated at the $\mathrm{VH}$ of the Universidade Estadual de Londrina, Paraná.

For dogs that were positive for scabies, $37.5 \%$ (3/8) had alopecia, pruritus, and desquamation, and
$33.3 \%(1 / 3)$ had crusts. Of the total scabies lesions, $30 \%(3 / 10)$ presented in the trunk region in dogs. For cats, lesion locations for both dermatophytosis and scabies were the same (Table 4).

No significant difference $(\mathrm{p}>0.05)$ was observed regarding the location of lesions for dermatophytosis in dogs and cats. For male dogs, however, the most affected sites $(\mathrm{p} \leq 0.05)$ were the trunk or a generalized presentation. Similar data were found by Palumbo et al. (2010), who observed $43 \%$ of the dogs presenting generalized lesions. 
Table 4 - Localization of lesions found in dogs and cats diagnosed with fungal and parasitic dermatological infections at the SAMC/ VH/ IFPB, Sousa, State of Paraíba, Brazil.

\begin{tabular}{|c|c|c|c|c|c|c|}
\hline \multirow{3}{*}{$\begin{array}{l}\text { Location of the } \\
\text { lesion }\end{array}$} & \multicolumn{3}{|c|}{ Dogs } & \multicolumn{3}{|c|}{ Cats } \\
\hline & & ermatophytes & Scabies & & Dermatophytes & Scabies \\
\hline & Attended & $\begin{array}{c}\text { Positives } \\
(\%)\end{array}$ & $\begin{array}{c}\text { Positives } \\
(\%)\end{array}$ & Attended & $\begin{array}{c}\text { Positives } \\
(\%)\end{array}$ & $\begin{array}{c}\text { Positives } \\
(\%)\end{array}$ \\
\hline Head & 5 & - & $2(40)^{\mathrm{a}}$ & 3 & $1(33,3)$ & $1(33,3)$ \\
\hline Snout & 5 & $1(20)$ & - & 3 & - & - \\
\hline Trunk & 6 & $1(16,7)$ & $3(50)^{\mathrm{b}}$ & 4 & $1(25)$ & $1(25)$ \\
\hline View Profile & 6 & $1(16,7)$ & - & - & - & - \\
\hline Head + muzzle & 4 & - & $1(25)^{\mathrm{a}}$ & - & - & - \\
\hline Trunk + muzzle & 9 & - & $1(11,1)^{\mathrm{a}}$ & 4 & - & - \\
\hline Generalized & 6 & $2(33,3)$ & $3(50)^{\mathrm{b}}$ & 3 & $1(33,3)$ & $1(33,3)$ \\
\hline Total & 41 & $5(12,2)$ & $10(24,4)$ & 17 & $3(17,6)$ & $3(17,6)$ \\
\hline
\end{tabular}

Values followed by different letters differ statistically from each other $\left({ }^{*} \mathrm{p} \leq 0,05\right)$.

\section{CONCLUSION}

Based on these data, we conclude that the occurrence of fungal and parasitic dermatopathies is high in the Small Animal Medical Clinic, Veterinary Hospital of the Instituto Federal da Paraíba - IFPB. The main dermatophytes found were $M$. canis in dogs and $M$. gypseum in cats. Among the parasitic diseases, $D$. canis was the most frequent pathogen for dogs, and $N$. cati was the most frequent for cats.

\section{REFERÊNCES}

BENSIGNOR, E. Comparasison de trois techniques diagnostiques de démodécie à demodex canis chez lechien. Pratique Médicale \& Chirurgicale de I'Animal de Compagnie, v. 38, n. 2, p. 167-171, 2003.

BOND, R. Superficial veterinary mycoses. Clinics in Dermatology, v. 28, n. 2, p. 226-236, 2010.

CAFARCHIA, C.; ROMITO, D.; SASANELLI, M.; LIA, R.; CAPELli, G.; OTRANTO, D. The epidemiology of canine and feline dermatophytoses in southern Italy. Mycoses, v. 47, n. 11/12, p. 508-513, 2004.

HILL, P. B.; LO, A.; EDEN, C. A. N.; HUNTLEY, S.; MOREY, V.; RAMSEY, S.; RICHARDSON, C.; SMITH, D. J.; SUTTON, C.; TAYLOR, M. D.; THORPE, E.; TIDMARSH, R.; WILLIAMS, V. Survey of the prevalence, diagnosis and treatment of dermatological conditions in small in general practice. The Veterinary Record, v. 158, p. 245-248, 2006.

HILL, P. B. Small Animal Dermatology - A practical guide to the diagnosis and management of skin diseases in dogs and cats. $12^{\text {nd }}$ Edition ButterworthHeinemann, 2002, 270-274p.

LIMA, S. R.; SILVA, W. A.; SILVEIRA, M. M.; NEVES, R. C. S. M.; DUTRA, V.; SOUSA, V. R. F. Isolation of dermatophytes from 50 asymptomatic domestic catstreated at the Federal University of Mato Grosso Veterinary Hospital in Cuiabá, MT. Semina: Ciências Agrárias, Londrina, v. 37, n. 4, p. 20032008, 2016.

MACHADO, M. L. S.; APPELT, C. E.; FERREIRO, L. Dermatófitos e leveduras isolados da pele de cães com dermatopatias diversas. Acta Scientiae Veterinariae., v. 32, n. 3, p.225-232, 2004.

MATOS, C. B.; MADRID, I. M.; SANTIN, R.; AZAMBUJA, R. H.; SCHUCH, I.; MEIRELES, M. C. A.; CLEFF, M. B. Dermatite multifatorial em um canino. Arquivo Brasileiro Medicina Veterinária e Zootecnia, v. 64, n. 6, p. 1478-1482, 2012.

MEGID, J.; RIBEIRO, M. A.; PAES, A. C. Doenças infecciosas de animais de produção e de companhia. $1^{a}$ ed. Rio de Janeiro: Roca, 2016. 887p.

MEDLEAU, L., HNILICA, A. Small Animal Dermatology - A Color Atlas and Therapeutic Guide. $2^{\text {nd }}$ Edition, Saunders Elsevier, 2006. 102-108p.

MORIELLO, K. A.; DEBOER, D. J. Dermatophytosis. In: GREENE, C. E. Infectious diseases of the dog and cat. $4^{\text {th }}$ ed. St Louis: Elsevier, p. 588-602. 2012.

MORIELLO, K.A. Feline Dermatophytosis. Journal of Feline Medicine and Surgery. v. 16, n. 5, p. 419431. 2014.

NEVES, R. C. S. M.; CRUZ, F. A. C. S.; LIMA, S. R.; TORRES, M. M.; DUTRA, V.; SOUSA, V. R. F. Retrospectiva das dermatofitoses em cães e gatos atendidos no Hospital Veterinário da Universidade Federal de Mato Grosso, nos anos de 2006 a 2008. Ciência Rural, v. 41, n. 8m p. 1405-1410, 2011.

NOBRE, M.; MEIRELES, M.; GASPAR, L. F. Malassezia pachydermatis e outros agentes infecciosos nas otites externas e dermatites em cães. Ciência Rural, v. 28, p. 447-452, 1998. 
NEUWALD, E. B.; RIBEIRO, V. L. S.; SEIBERT, M.; TORRES, J. R. Prevalência das acarioses de cães e gatos diagnosticados no laboratório de entomologia da FAVET/UFGS de 2000 a 2003. In: CONGRESSO BRASILEIRO DE CLÍNICOS VETERINÁRIOS DE PEQUENOS ANIMAIS, 25, Gramado. Anais... Gramado: ANCLIVEPA, 2004, p.40.

NWEZE, E. I. Dermatophytoses in domesticated animals. Revista do Instituto de Medicina Tropical de São Paulo, v. 53, n. 2, p. 94-99, 2011.

PALUMBO, M. I. P.; MACHADO, L. H. A.; PAES, A. C.; MANGIA, S. H.; MOTTA, R.G. Estudo Epidemiológico das Dermatofitoses em Cães e Gatos Atendidos no Serviço de Dermatologia da Faculdade de Medicina Veterinária e Zootecnia da UNESP Botucatu. Semina: Ciências Agrárias, v. 31, n. 2, p. 459- 468, 2010.

PEREIRA, S. A.; SCHUBACH, T. M. P.; FIGUEIREDO, F. B. Demodicose associada à esporotricose e pediculose em gato co-infectado por FIV/FeLV. Acta Scientiae Veterinariae, v. 33, n. 1, p. 75-78, 2005

PICCININ, A.; FERRARI, M. L. O. P.; PRADO M. O.; SPIGOLON, Z. Sarna Sarcóptica em cães. Revista Científica Eletrônica de Medicina Veterinária, v. 7, n. 10 , p. $1-5,2008$.
ROCHA, G. S.; AHID, S. M. M.; BEZERRA, A. C. D. S.; FILGUEIRA, K. D.; SANTOS, J. P. S. Frequência de ácaros em cães e gatos no Município de Mossoró, Rio Grande do Norte. Acta Scientiae Veterinariae, v. 36, n. 3, p. 263-266, 2008.

SANTAREM, V. Demodiciose canina: revisão. Revista Clínica Veterinária, v. 12, n. 69, p. 86-95, 2007.

SIDRIM, J. J. C.; ROCHA, M. F. G. Micologia médica à luz de autores contemporâneos. $1^{\mathrm{a}}$ ed. Rio de Janeiro: Guanabara Koogan, 2004. 408p.

SILVA, R. P. B.; BELETTINI, S. T.; STEL, R. F.; MARTINS, L. A.; PACHALY, J. R. Sarna demodécica canina e suas novas perspectivas de tratamento revisão. Arquivo de Ciências Veterinárias e Zoologia da UNIPAR, v. 11, n. 2, p. 139-151, 2008.

SCOTT, D. W.; MILLER, W. H.; GRIFFIN, C.E. Chapter 6 -Parasitic Skin Diseases.Canine Demodicosis. Small Animal Dermatology. $6^{\text {a }}$ ed. Philadelphia: Saunders Company, 2004. 457-474p.

STREINER, D. L.; NORMAN, G. R. Biostatistics the bare essentials. St. Louis: Mosby -Year Book, 1994. $260 \mathrm{p}$. 